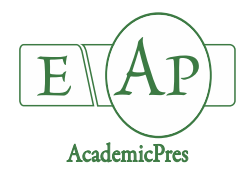

Naghmouchi S and Alsubeie M (2020)

Notulae Botanicae Horti Agrobotanici Cluj-Napoca 48(3):1600-1612

DOI: $10.15835 /$ nbha48312025

Research Article

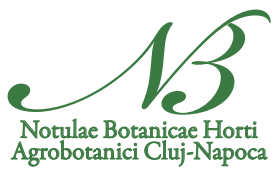

\title{
Biochemical profile, antioxidant capacity and allelopathic effects from five Ziziphyus spina-christi (L.) provenances growing wild in Saudi Arabia
}

\author{
Souheila NAGHMOUCHI ${ }^{1}$, Moodi ALSUBEIE ${ }^{2 *}$ \\ ${ }^{1}$ University of Tunis, National Research Institute of Rural Engineering, Water, and Forestry, Carthage, Street of Hedi Karay BP. \\ No10 Ariana2080,Tunisia; den_souheila@yahoo.fr \\ ${ }^{2}$ Imam Mohammed Ibn Saud Islamic University, College of Sciences, Biology Department, Riyadh, \\ Kingdom of Saudi Arabia; swc225@hotmail.com (*corresponding author)
}

\begin{abstract}
The aim of this work was to evaluate phenolic profile, antioxidant capacity and allelopathic effects of six Ziziphyus spina-christi provenances in Saudi Arabia. Total phenols, flavonoids, tannins and antioxidant activity were evaluated. Total phenols, condensed tannins and total flavonoids were present at levels of 62.29 $\mathrm{mg} \mathrm{GAE} / \mathrm{g} \mathrm{DM}, 16.69 \mathrm{mg} \mathrm{CE} / \mathrm{g} \mathrm{DM}$ and $15.45 \mu \mathrm{g} \mathrm{mg} \mathrm{QE/g} \mathrm{DM,} \mathrm{respectively.} \mathrm{The} \mathrm{high} \mathrm{antioxidant} \mathrm{activity}$ $(0.15 \mathrm{mg} / \mathrm{ml})$ was noted in Mecca Road provenance. The highest germination, shoots and radicle lengths of tested species were observed in At-taif provenance. $Z$. spina-christi leaf extracts may be suggested in foods and pharmaceutical industries. Leaf extracts could also provide a natural herbicide with a positive impact on the environment. Provenance of Jizan, Northern Borders and Mecca Road were shown to be particularly effective in antioxidant capacity, while Provenance of Riyadh and Northern Borders shown to have the best allelopathic activity.
\end{abstract}

Keywords: allelopathic effects; antioxidant activity; provenance; Saudi Arabia; secondary metabolites; Ziziphyus spina-christi

\section{Introduction}

Ziziphyus spina-christi ( $Z$. spina-christi), an evergreen tree, had been credited with many medicinal fields of applications, including immunity and nutrition (Jiang et al., 2007). The fruit of $Z$. spina-christi, as known as 'Nbeg', tasted like a mixture of dates and apples and was usually eaten fresh or dried (Bukar et al., 2015). Many glycoproteins, proteoglycans and glycopeptides had been identified from the $Z$. spina-christi honey (Seif Eldin et al., 2015). In addition, the allelopathy activity, an important biological process in ecology, had been widely employed to protect crops and replace herbicides, fungicides and insecticides being harmful to the environment. The leaf extracts of $Z$. spina-christi presented allelopathic effects on the growth and the development of other plants or micro-organisms (Bhadoria et al., 2011). Ziziphyus spina-christi (sidr) is a shrub, sometimes a tree, native to a vast area of Africa stretching from Mauritania to West Africa. In the Kingdom of Saudi Arabia, it is a medicinal plant for many diseases (Alansi et al., 2016). The genus Ziziphyus 
belongs to the family of Rhamnaceae with about 85 species and Ziziphyus is the most common plants of economic importance in Saudi Arabia and are the major floral sources of high-valued expensive honeys (Alqarni et al., 2015; Alqarni, 2015). Z. spina-christi can grow either as a tree or as a shrub. The leaves are short, the flowers are pedunculated and the yellow or red fruits are edible (Chaudhary et al., 2001). Ziziphyus jujuba, a plant locally grown in Saudi Arabia and used extensively for its health benefits. The medicinal properties of Ziziphyus tree, also known as Nabq or Sidr, were also recognized and have been in use in Pharaonic carpentry, diet, and medicine (El-Ansary et al., 2018).Z. spina-christ i is a medicinal plant and its leaf extract (peptide and cyclopeptide alkaloids) has neuroprotective and therapeutic roles against pentylenetetrazol convulsant effect (Waggas et al., 2010). The Quran mentions the sidr tree twice and accordingly it is highly respected by the Muslims throughout the Middle East (Farooqi, 1997). It is traditionally used in the Muslim countries to wash the bodies of dead Muslims prior to burial, with water in which Ziziphyus jujuba leaves had been soaked (Dafni et al., 2005. In Saudi Arabia, it is used for the treatment of many diseases like wounds, ulcers, etc. Mizrahi et al. (2002) reported that Ziziphyus species are cultivated in hot and arid regions. Some pharmacological screening studies indicated that Z. spina-christi leaves appear to be a safe alternative to lower the blood glucose level. Honeys originating from Sidr (Ziziphyus spina-christi L.) trees in Saudi Arabia exhibited substantial antimicrobial activity against pathogenic (Owayss et al., 2020). Leaves of Ziziphyus jujuba contain a compound known as Ziziphyus which demonstrates medicinal properties and is commonly used in traditional medicine. Among the medicinal properties of Ziziphyus jujube are sedative properties, anticancer, antioxidants, antimicrobial and anti-inflammatory effects (Li et al., 2005; Abdel-Zaher et al., 2014). In Saudi Arabia, Ziziphyus spina-christi is one of the most popular species of Ziziphyus. It is a wild and cultivated plant distributed in the Middle East, Pakistan and in the North and East of Africa (Alansi et al., 2016).

In this study, total phenolic, total flavonoid, condensed tannin contents and antioxidant activity of Ziziphyus spina-christi methanolic leaf extracts harvested from six Saudi Arabia provenances were evaluated and compared. In vitro allelopathic activities of aqueous extracts of the leaves were also tested on Trigonella foenum-graecum and Lens culinaris seeds.

\section{Materials and Methods}

\section{Plant material}

Leaves of Z. spina-christi were sampled from At-taif, Riyadh, Jizan, Northern Borders, Mecca Road, Jeddah (Figure 1). The plant species were collected (200-250 g per species) during the vegetative phase. The harvested provenances of Z. spina-christiwere authenticated and named using existing literature (Cope, 1985; Chaudhary and Akram, 1987; Mighaid, 1996; Collenette, 1999; Chaudhary, 1999-2001; Chaudhary, 1999, 2000, 2001; Al-Hassan, 2006). The harvested plant samples were processed (powdered at around 100 mesh) then dried in the shade at room temperature for two weeks) and finally stored in in plastic bags in the dark until chemical analysis.

\section{Preparation of the plant extracts}

The aerial part of each provenance was finely powdered and used for the different biochemical assays. The solvent is used in order to obtain plant extracts solutions $(1 \mathrm{~g} / 10 \mathrm{ml})$, which were macerated for $24 \mathrm{~h}$ in shaking conditions $(50 \mathrm{rpm}$ ) and used to assay the total content of polyphenols, the total content of flavonoids and the total antioxidant activity (DPPH test). Then extracts were pooled and concentrated under vacuum (Hammi et al., 2015). 


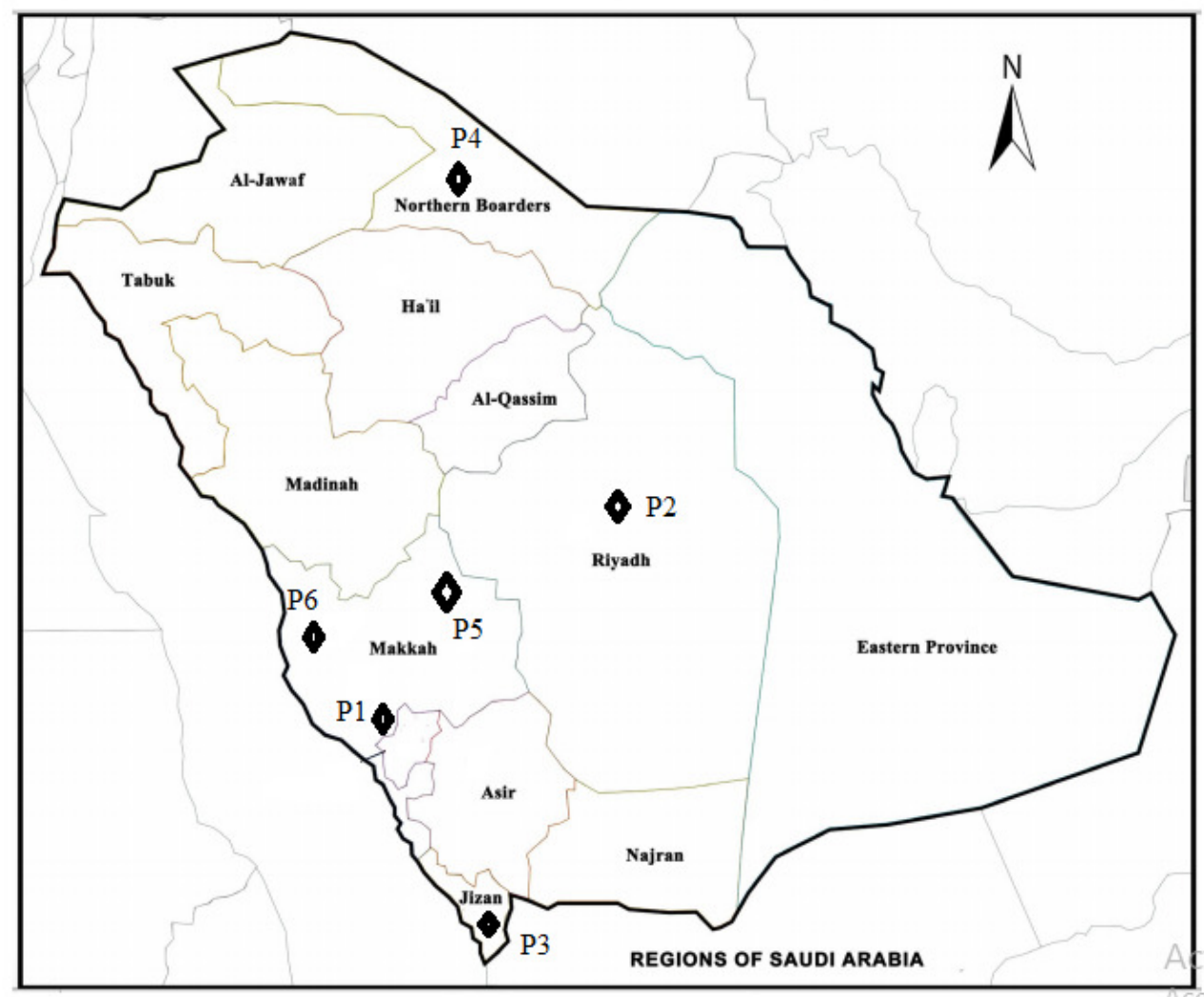

Figure 1. Localities of six Ziziphus spina-christi provenances in Saudi Arabia (P1: At-taif; P2: Riyadh; P3: Jizan; P4: Northern Borders; P5: Mecca Road; P6: Jeddah

\section{Total polyphenol content}

Total phenolics were determined with Folin-Ciocalteu assay as per the Singleton et al. (1999) method which was slightly modified by Deawanto et al. (2002). The results are obtained using a UV/Vis Jenway-6300 spectrophotometer (United Kingdom) under $760 \mathrm{~nm}$. The total phenolics content was expressed as milligrams of Gallic acid equivalents per gram of dry matter ( $\mathrm{mg} \mathrm{GAE} / \mathrm{g} \mathrm{DM}$ ) through the calibration curve of Gallic acid. The sample was analysed in three replications (Rouz et al., 2015).

\section{Total flavonoid contents}

Total flavonoid contents were determined using the Aluminium trichloride method (Rice-Evans et al. 1996; Popova et al., 2004;). $1 \mathrm{ml}$ of $\mathrm{AlCl}_{3}$ (2\%) was added to $1 \mathrm{ml}$ of plant extract. The volume was adjusted to $25 \mathrm{ml}$ with methanol and thoroughly mixed. The absorption was measured after $40 \mathrm{~min}$ by a Shimadzu UV160 (Tokyo, Japan) spectrophotometer at $420 \mathrm{~nm}$. Total flavonoids were expressed in milligrams quercetin equivalents per gram of dry matter $(\mathrm{mg} \mathrm{QE} / \mathrm{g} \mathrm{DM})$ through the calibration curve of quercetin. All measurements were repeated three times for accuracy and reliability (Elaloui et al., 2016).

\section{Condensed tannin contents}

Condensed tannin levels were assayed following the Earp et al. (1981) method. $1 \mathrm{ml}$ of vanillin (1\%) mixed with $4 \mathrm{ml}$ of $\mathrm{HCl}$ were added to $200 \mu \mathrm{l}$ of leaf extracts and incubated $20 \mathrm{~min}$ in obscurity. Catechin was used as a standard $(0-1250 \mu \mathrm{g} / \mathrm{ml})$ and the results were expressed as microgram catechin equivalent per gram dry weight $(\mu \mathrm{g} \mathrm{CE} / \mathrm{g} \mathrm{DM})$. All measurements were performed in three replications. After agitation, the absorbance was read at $500 \mathrm{~nm}$ using a Jenway 6100 spectrophotometer. 
Antioxidant activity

In test tubes $2.36 \mathrm{mg}$ of DPPH, previously dissolved in $100 \mathrm{ml}$ of ethanol, was mixed and incubated in obscurity. Different concentrations $(0.75 ; 0.5 ; 0.25 ; 0.125 \mu \mathrm{g} / \mathrm{ml})$ were prepared from $1 \mathrm{mg} / \mathrm{ml}$ of each leaf extracts. The control sample was done using ethanol and DPPH. The absorbance was measured at $490 \mathrm{~nm}$ after incubation for $30 \mathrm{~min}$ in dark. Measurements for each experiment were done in triplicate. Antioxidant activity expressed as inhibitory effect of the DPPH radical was calculated using this formula:

The percentage of inhibition $=[(\mathrm{A} 0-\mathrm{Ac}) / \mathrm{A} 0] \times 100$

Where $\mathrm{A} 0$ was the absorbance of the control and Ac was the absorbance of the plant extract/ standard.

The IC 50 value, the concentration (in $\mu \mathrm{g} / \mathrm{ml}$ ) of the compound required to scavenge DPPH radical by 50, were determined graphically by the linear regression (Basuny et al., 2013).

\section{Allelopathic activity of Ziziphyus spina-christi leaf aqueous extracts}

Extracts were obtained by macerating from the Ziziphyus spina-christi provenances leaf extracts as various concentrations: $5 \mathrm{~g}, 20 \mathrm{~g}, 40 \mathrm{~g}, 60 \mathrm{~g}$ and $100 \mathrm{~g}$ powdered plant in 1 litre of distilled water for $24 \mathrm{~h}$. The solutions were filtered through double layers of muslin cloth followed by filter paper. Trigonella foenumgraecum and Lens culinaris seeds were sterilized with $0.3 \%$ calcium hypochlorite, rinsed in distilled water, and dried on filter paper in the laboratory at room temperature for 7 days. For germination, two layers of filter papers were placed in 90-mm-diameter glass petri dishes. Twenty seeds were placed in each petri dish, followed by $02 \mathrm{~mL}$ of plant extract. The control groups were each given $2 \mathrm{ml}$ of deionized water and leave at room temperature $\left(25^{\circ} \mathrm{C}\right)$. The Petri dishes were sealed with plastic wrap to prevent the loss of moisture and avoid contamination. Starting from the first day after the experiment began, germinated seeds were counted and removed daily. The experimental design was carried out as a randomized complete block (RCB) with 5 replications. The germination percentage (GP) was calculated. For growth bioassays, the seeds of Trigonella foenum-graecum and Lens culinaris were germinated on filter paper in the dark at room temperature $\left(25^{\circ} \mathrm{C}\right)$ and a photoperiod of 16 hours. Fifteen germinated seeds were transferred to petri dishes, which were filed with $25 \mathrm{~g}$ of sterilized quartz sand, and $02 \mathrm{~mL}$ of tested extract was added. In addition, control sample was added to the experiment without any treatment. Shoot (SL) and root lengths (RL) of seedlings were measured 15 days after treatment (DAT).

\section{Statistical analysis}

A descriptive analysis was performed to describe the entire results within each kind of test. Concerning the biochemical composition analysis and antioxidant activity a one-way analysis of variance (ANOVA oneway) followed by Duncan test was performed to test possible significant differences among mean values from different provenances. The level of significance was set at $\mathrm{P}<0.05$ for all analyses. Statistical analyses were performed using PSS v.23 software.

\section{Results}

Analysis of secondary metabolites and antioxidant properties

Total polyphenol, total flavonoid and tannins contents

Total polyphenol levels varied from $23.65 \mathrm{mg} \mathrm{GAE} / \mathrm{g} \mathrm{DM}$ of the At-taif provenance to $62.29 \mathrm{mg} \mathrm{GAE} / \mathrm{g}$ DM of the Mecca Road provenance (Table 1). The Jizan provenance has an important total polyphenol level (50.63 GAE/g DM). The relative values of total flavonoids (Table 1) oscillated between 6.35 (At-taif) and $15.45 \mathrm{mg}$ QE/g DM (Jeddah). The Riyadh provenance has an important total polyphenol level (12.68 QE g/g $\mathrm{DM})$. As we see in these results, the tree of Ziziphyus spina-christi in At-taif was the most stressed tree provenance. Leaf extracts of Jizan Z. spina-christi found to contain higher amounts of tannins (16.69 mg CE/g 
$\mathrm{DM})$ as compared to provenances of At-taif (12.36 mg CE/g DM), Riyadh ( $9.25 \mathrm{mg} \mathrm{CE} / \mathrm{g} \mathrm{DM})$ Northern Borders (11.26 mg CE/g DM) Mecca Road (7.16 mg CE/g DM) and Jeddah (14.39 mg CE/g DM).

\section{$\underline{\text { Antioxidant activity }}$}

The antioxidant activity ranged between $0.15 \mathrm{mg} / \mathrm{mL}$ and $0.06 \mathrm{mg} / \mathrm{mL}$, respectively (Table 2). The provenance of At-taif, Riyadh and Jeddah provenances have a lower value of IC50 compared with Jizan, Northern Borders and Mecca Road provenances.

Table 1. Phytochemical composition extracts of six Ziziphus spina-christi provenances

\begin{tabular}{|c|c|c|c|}
\hline Provenances & $\begin{array}{c}\text { Total polyphenol contents } \\
(\mathrm{mg} \mathrm{GAE} / \mathrm{g} \text { DM })\end{array}$ & $\begin{array}{c}\text { Total flavonoid content } \\
(\mathrm{mg} \text { QE/g DM })\end{array}$ & $\begin{array}{c}\text { Condensed tannins } \\
(\mathrm{mg} \text { CE/g DM })\end{array}$ \\
\hline At-taif & $23.65 \pm 0.35^{\mathrm{f}}$ & $6.35 \pm 0.32^{\mathrm{e}}$ & $12.36 \pm 0.48^{\mathrm{c}}$ \\
\hline Riyadh & $36.65 \pm 0.51^{\mathrm{e}}$ & $12.68 \pm 0.26^{\mathrm{b}}$ & $9.25 \pm 0.13^{\mathrm{e}}$ \\
\hline Jizan & $50.63 \pm 0.26^{\mathrm{b}}$ & $9.45 \pm 0.27^{\mathrm{c}}$ & $16.69 \pm 0.42^{\mathrm{a}}$ \\
\hline Northern Borders & $43.57 \pm 0.034^{\mathrm{c}}$ & $7.68 \pm 0.49^{\mathrm{f}}$ & $11.26 \pm 0.11^{\mathrm{d}}$ \\
\hline Mecca Road & $62.29 \pm 0.28^{\mathrm{a}}$ & $8.59 \pm 0.42^{\mathrm{d}}$ & $7.16 \pm 0.92^{\mathrm{f}}$ \\
\hline Jeddah & $42.08 \pm 0.38^{\mathrm{d}}$ & $15.45 \pm 0.76^{\mathrm{a}}$ & $14.39 \pm 0.22^{\mathrm{b}}$ \\
\hline
\end{tabular}

Data are presented as mean values \pm standard deviation $(\mathrm{n}=3)$. Statistical analysis: ANOVA test and DUNCAN test. The different letters above the values in the same column indicate significant differences $(p<0.05)$. Values with the same superscript letters in the same column are not significant.

Table 2. Antioxidant activity of plant extracts

\begin{tabular}{|c|c|}
\hline Provenances & DPPH $(\mathrm{IC} 50, \mathrm{mg} / \mathrm{ml})$ \\
\hline At-taif & $0.06 \pm 0.005^{\mathrm{f}}$ \\
\hline Riyadh & $0.08 \pm 0.015^{\mathrm{d}}$ \\
\hline Jizan & $0.13 \pm 0.036^{\mathrm{b}}$ \\
\hline Northern Borders & $0.10 \pm 0.003^{\mathrm{c}}$ \\
\hline Mecca Road & $0.15 \pm 0.05^{\mathrm{a}}$ \\
\hline Jeddah & $0.07 \pm 0.012^{\mathrm{e}}$ \\
\hline
\end{tabular}

Data are presented as mean values \pm Standard deviation $(n=3)$. Statistical analysis: ANOVA test and

Duncan test $(\mathrm{p}<0.05)$. Values with the same superscript letters in the same column are not significant.

Effects of aqueous Z. spina-christi leaf extracts on L. culinaris and T. foenum-graecum

Effects on seed germination

T. foenum-graecum seeds were more sensitive than those of $L$. culinarisseeds after treatment by aqueous leaf extracts with concentrations of 60 and $100 \mathrm{~g} / \mathrm{l}$ (Tables 3 and 4). All extract of provenances of Ziziphyus have a negative effect on germination of $T$. foenum-graecum and $L$. culinaris seeds. The extract of Riyadh and Northern Borders provenance have a very remarkable influence on the germination of $T$. foenum-graecum ( 3 and $4 \%$ at $100 \mathrm{~g} / \mathrm{l}$ respectively) and the germination of L. culinaris ( $9 \%$ and $8 \%$ respectively at $100 \mathrm{~g} / \mathrm{l}$ ).

Effects on root and shoot lengths

Root lengths are very sensitive to aqueous Z. spina-christileaf extracts (Tables 3 and 4). Compared with other provenances, the two provenances which have a great effect on the root length of Trigonella foenumgraecum L. are those of Riyadh (10 and $16 \mathrm{~mm}$ at 20 and $100 \mathrm{~g} / 1$ respectively) and Northern Borders (15 and $2 \mathrm{~mm}$ at 60 and $100 \mathrm{~g} / 1$ respectively). These two provenances also have the greatest effect on the root length of Lens culinaris L.: 13 and $9 \mathrm{~mm}$ at 60 and $100 \mathrm{~g} / \mathrm{l}$ respectively for Riyadh provenances and 14 and $8 \mathrm{~mm}$ at 60 and $100 \mathrm{~g} / \mathrm{l}$ for Northern Borders provenances (Tables 3 and 4). Shoot lengths are very sensitive to aqueous Z. spina-christileaf extracts (Tables 3 and 4). Riyadh Northern Borders provenance have a very negative effect on seedling shoots of Trigonella foenum-graecum L. compared with other provenances with 23 and $8 \mathrm{~mm}$ at 60 and $100 \mathrm{~g} / 1$ respectively and 18 and $6 \mathrm{~mm}$ at 60 and $100 \mathrm{~g} / 1$ respectively. Riyadh Northern Borders 
provenance have a very negative effect on seedling shoots of Lens culinaris L. compared with other provenances with 15 and $8 \mathrm{~mm}$ at 60 and $100 \mathrm{~g} / 1$ respectively and 24 and $13 \mathrm{~mm}$ at 60 and $100 \mathrm{~g} / 1$ respectively (Tables 3 and 4 ).

Table 3. Effects of different aqueous leaf extracts of six provenances of $Z$. spina-christi on the growth of Trigonella foenum-graecum $\mathrm{L}$.

\begin{tabular}{|c|c|c|c|c|c|c|c|}
\hline Parameters & $\begin{array}{c}\text { Aqueous extract } \\
\text { concentration } \\
(\mathrm{g} / \mathrm{l})\end{array}$ & $\begin{array}{c}\text { At-taif } \\
\text { provenance }\end{array}$ & $\begin{array}{c}\text { Riyadh } \\
\text { provenance }\end{array}$ & $\begin{array}{c}\text { Jizan } \\
\text { provenance }\end{array}$ & $\begin{array}{c}\text { Northern } \\
\text { Borders } \\
\text { provenance }\end{array}$ & $\begin{array}{l}\text { Mecca Road } \\
\text { provenance }\end{array}$ & $\begin{array}{c}\text { Jeddah } \\
\text { provenance }\end{array}$ \\
\hline \multirow{6}{*}{$\begin{array}{l}\text { Germination } \\
\text { capacity (\%) at } \\
7 \text { DAT }\end{array}$} & 0 & $75 \pm 2.36^{\mathrm{a}}$ & $92 \pm 3.21^{a}$ & $85 \pm 4.21^{a}$ & $87 \pm 1.26^{a}$ & $77 \pm 3.26^{a}$ & $84 \pm 2.41^{a}$ \\
\hline & 5 & $60 \pm 1.25^{b}$ & $52 \pm 2.36^{\mathrm{b}}$ & $57 \pm 4.15^{b}$ & $53 \pm 2.15^{b}$ & $50 \pm 2.35^{b}$ & $52 \pm 3.97^{b}$ \\
\hline & 20 & $42 \pm 2.35^{c}$ & $38 \pm 1.24^{\mathrm{c}}$ & $33 \pm 3.45^{c}$ & $31 \pm 3.40^{c}$ & $31 \pm 1.06^{c}$ & $37 \pm 1.23^{c}$ \\
\hline & 40 & $23 \pm 1.12^{\mathrm{d}}$ & $26 \pm 1.98^{\mathrm{d}}$ & $21 \pm 2.15^{\mathrm{d}}$ & $28 \pm 1.02^{\mathrm{d}}$ & $22 \pm 0.68^{d}$ & $26 \pm 3.15^{\mathrm{d}}$ \\
\hline & 60 & $15 \pm 3.26^{\mathrm{e}}$ & $10 \pm 0.98^{\mathrm{e}}$ & $18 \pm 1.02^{\mathrm{e}}$ & $12 \pm 1.29^{\mathrm{e}}$ & $17 \pm 1.03^{\mathrm{e}}$ & $21 \pm 1.02^{\mathrm{e}}$ \\
\hline & 100 & $08 \pm 3.26^{f}$ & $04 \pm 4.16^{f}$ & $12 \pm 5.14^{\mathrm{f}}$ & $02 \pm 1.24^{\mathrm{f}}$ & $11 \pm 2.49^{f}$ & $10 \pm 0.26^{\mathrm{f}}$ \\
\hline \multirow{6}{*}{$\begin{array}{l}\text { Seedling root } \\
\text { length }(\mathrm{mm}) \\
\text { at } 15 \mathrm{DAT}\end{array}$} & 0 & $52.15 \pm 1.20^{\mathrm{a}}$ & $65.15 \pm 2.15^{a}$ & $49.25 \pm 1.64^{a}$ & $54.12 \pm 2.36^{a}$ & $56.34 \pm 2.10^{\mathrm{a}}$ & $53.12 \pm 1.35^{\mathrm{a}}$ \\
\hline & 5 & $42.35 \pm 2.13^{b}$ & $54.12 \pm 3.15^{b}$ & $46.35 \pm 3.16^{b}$ & $48.26 \pm 3.12^{b}$ & $51.42 \pm 0.96^{b}$ & $50.14 \pm 2.34^{b}$ \\
\hline & 20 & $33.25 \pm 1.23^{c}$ & $43.12 \pm 0.95^{c}$ & $42.15 \pm 2.15^{b c}$ & $34.16 \pm 0.95^{c}$ & $45.12 \pm 2.67^{c}$ & $42.15 \pm 0.95^{\mathrm{bc}}$ \\
\hline & 40 & $24.15 \pm 2.15^{\mathrm{de}}$ & $33.15 \pm 2.15^{\mathrm{de}}$ & $33.15 \pm 1.42^{\mathrm{d}}$ & $23.15 \pm 2.13^{d}$ & $32.15 \pm 0.52^{\mathrm{d}}$ & $39.45 \pm 3.15^{\mathrm{d}}$ \\
\hline & 60 & $18.65 \pm 3.26^{\mathrm{e}}$ & $16.54 \pm 3.21^{\mathrm{e}}$ & $25.35 \pm 0.92^{\mathrm{e}}$ & $15.24 \pm 2.57^{\mathrm{e}}$ & $23.15 \pm 1.04^{\mathrm{e}}$ & $32.65 \pm 2.48^{e}$ \\
\hline & 100 & $15.24 \pm 1.05^{f}$ & $8.65 \pm 1.05^{\mathrm{f}}$ & $14.25 \pm 1.37^{\mathrm{f}}$ & $4.36 \pm 4.12^{f}$ & $15.64 \pm 2.67^{f}$ & $16.84 \pm 1.42^{f}$ \\
\hline \multirow{6}{*}{$\begin{array}{l}\text { Seedling shoot } \\
\text { lenght }(\mathrm{mm}) \\
\text { at } 15 \mathrm{DAT}\end{array}$} & 0 & $65.45 \pm 0.96^{\mathrm{a}}$ & $64.58 \pm 0.95^{a}$ & $75.12 \pm 2.42^{\mathrm{a}}$ & $68.45 \pm 2.10^{\mathrm{a}}$ & $69.48 \pm 2.35^{a}$ & $66.25 \pm 2.39^{a}$ \\
\hline & 5 & $48.25 \pm 2.15^{b}$ & $53.12 \pm 4.35^{b}$ & $59.85 \pm 0.75^{b}$ & $63.25 \pm 3.15^{b}$ & $64.12 \pm 3.45^{b}$ & $52.46 \pm 2.38^{b}$ \\
\hline & 20 & $36.45 \pm 3.15^{c}$ & $41.26 \pm 2.09^{b c}$ & $45.16 \pm 3.15^{c}$ & $54.12 \pm 1.03^{c}$ & $54.13 \pm 2.03^{c}$ & $41.36 \pm 2.98^{c}$ \\
\hline & 40 & $23.54 \pm 0.67^{d}$ & $33.16 \pm 3.45^{\mathrm{d}}$ & $41.13 \pm 2.37^{\mathrm{dc}}$ & $33.15 \pm 2.35^{d}$ & $34.15 \pm 2.34^{\mathrm{d}}$ & $34.95 \pm 3.45^{d}$ \\
\hline & 60 & $15.24 \pm 2.17^{\mathrm{e}}$ & $23.45 \pm 2.03^{\mathrm{e}}$ & $33.12 \pm 0.93^{\mathrm{e}}$ & $18.46 \pm 0.68^{\mathrm{e}}$ & $21.23 \pm 1.06^{\mathrm{e}}$ & $19.65 \pm 2.34^{\mathrm{e}}$ \\
\hline & 100 & $12.25 \pm 1.37^{\mathrm{f}}$ & $8.46 \pm 2.15^{f}$ & $19.35 \pm 3.15^{\mathrm{f}}$ & $6.45 \pm 1.35^{f}$ & $12.45 \pm .67^{\mathrm{f}}$ & $10.39 \pm 1.06^{\mathrm{f}}$ \\
\hline
\end{tabular}

Data are presented as mean values \pm Standard deviation $(n=3)$. Statistical analysis: ANOVA test and DUNCAN test $(\mathrm{p}<0.05)$. Values with the same superscript letters in the same column are not significant.

Table 4. Effects of different aqueous leaf extracts of six provenances of $Z$. spina-christi on the growth of Lens culinaris $\mathrm{L}$.

\begin{tabular}{|c|c|c|c|c|c|c|c|}
\hline Parameters & $\begin{array}{c}\text { Aqueous } \\
\text { extract } \\
\text { concentration } \\
(\mathrm{g} / \mathrm{l}) \\
\end{array}$ & $\begin{array}{c}\text { At-taif } \\
\text { provenance }\end{array}$ & $\begin{array}{c}\text { Riyadh } \\
\text { provenance }\end{array}$ & $\begin{array}{l}\text { Jizan } \\
\text { provenance }\end{array}$ & $\begin{array}{l}\text { Northern } \\
\text { Borders } \\
\text { provenance }\end{array}$ & $\begin{array}{l}\text { Mecca Road } \\
\text { provenance }\end{array}$ & $\begin{array}{c}\text { Jeddah } \\
\text { provenance }\end{array}$ \\
\hline \multirow{6}{*}{$\begin{array}{c}\text { Germination } \\
\text { capacity (\%) at } \\
7 \text { DAT }\end{array}$} & 0 & $89 \pm 3.16^{a}$ & $82 \pm 2.19^{\mathrm{a}}$ & $78 \pm 4.16^{\mathrm{a}}$ & $85 \pm 1.18^{\mathrm{a}}$ & $72 \pm 5.48^{a}$ & $91 \pm 1.46^{\mathrm{a}}$ \\
\hline & 5 & $75 \pm 2.31^{\mathrm{ab}}$ & $79 \pm 2.35^{\mathrm{ab}}$ & $69 \pm 6.35^{\mathrm{ab}}$ & $72 \pm 0.93^{\mathrm{ab}}$ & $70 \pm 2.35^{b}$ & $85 \pm 2.13^{\mathrm{ab}}$ \\
\hline & 20 & $60 \pm 2.03^{b}$ & $63 \pm 3.21^{c}$ & $65 \pm 3.45^{c}$ & $62 \pm 5.15^{c}$ & $63 \pm 0.74^{c}$ & $61 \pm 0.85^{c}$ \\
\hline & 40 & $36 \pm 2.15^{c}$ & $41 \pm 2.45^{\mathrm{d}}$ & $31 \pm 2.36^{d}$ & $24 \pm 1.26^{\mathrm{dc}}$ & $34 \pm 3.15^{d}$ & $36 \pm 3.21^{\mathrm{d}}$ \\
\hline & 60 & $23 \pm 1.06^{\mathrm{cd}}$ & $35 \pm 3.45^{\mathrm{e}}$ & $19 \pm 0.95^{\mathrm{e}}$ & $33 \pm 1.07^{\mathrm{e}}$ & $21 \pm 2.15^{\mathrm{e}}$ & $15 \pm 2.35^{\mathrm{e}}$ \\
\hline & 100 & $14 \pm 1.68^{d}$ & $9 \pm 0.19^{f}$ & $15 \pm 3.12^{f}$ & $8 \pm 2.85^{f}$ & $19 \pm 2.06^{f}$ & $17 \pm 0.69^{f}$ \\
\hline \multirow{6}{*}{$\begin{array}{l}\text { Seedling root } \\
\text { length }(\mathrm{mm}) \\
\text { at } 15 \mathrm{DAT}\end{array}$} & 0 & $42.35 \pm 0.68^{a}$ & $38.68 \pm 2.36^{a}$ & $44.25 \pm 2.18^{a}$ & $41.26 \pm 1.04^{a}$ & $44.68 \pm 0.95^{a}$ & $45.69 \pm 1.25^{\mathrm{a}}$ \\
\hline & 5 & $35.25 \pm 2.15^{b}$ & $32.15 \pm 1.02^{b}$ & $30.25 \pm 3.49^{b}$ & $33.15 \pm 3.25^{b}$ & $30.78 \pm 1.02^{b}$ & $36.45 \pm 2.04^{b}$ \\
\hline & 20 & $28.15 \pm 2.06^{\mathrm{bc}}$ & $29.65 \pm 2.18^{c}$ & $21.25 \pm 1.42^{c}$ & $25.64 \pm 2.38^{c}$ & $29.58 \pm 1.35^{\mathrm{bc}}$ & $30.42 \pm 1.52^{b c}$ \\
\hline & 40 & $24.15 \pm 0.24^{\mathrm{dc}}$ & $23.54 \pm 0.58^{d}$ & $18.68 \pm 2.15^{d}$ & $21.25 \pm 1.45^{\mathrm{d}}$ & $19.65 \pm 2.04^{d}$ & $29.25 \pm 3.16^{\mathrm{d}}$ \\
\hline & 60 & $16.42 \pm 2.35^{\mathrm{e}}$ & $13.67 \pm 2.48^{\mathrm{e}}$ & $17.25 \pm 3.45^{\mathrm{e}}$ & $14.25 \pm 0.93^{\mathrm{e}}$ & $17.27 \pm 3.12^{\mathrm{e}}$ & $23.15 \pm 2.45^{\mathrm{e}}$ \\
\hline & 100 & $10.26 \pm 1.29^{f}$ & $9.36 \pm 1.09^{f}$ & $14.16 \pm 2.45^{f}$ & $8.16 \pm 1.04^{\mathrm{f}}$ & $15.14 \pm 0.73^{\mathrm{f}}$ & $18.15 \pm 3.48^{f}$ \\
\hline \multirow{6}{*}{$\begin{array}{l}\text { Seedling shoot } \\
\text { lenght }(\mathrm{mm}) \\
\text { at } 15 \mathrm{DAT}\end{array}$} & 0 & $32.65 \pm 3.21^{\mathrm{a}}$ & $33.25 \pm 1.23 \mathrm{a}$ & $37.25 \pm 0.42^{\mathrm{a}}$ & $34.68 \pm 0.68^{a}$ & $36.58 \pm 1.09^{a}$ & $35.18 \pm 3.21^{\mathrm{a}}$ \\
\hline & 5 & $31.15 \pm 1.45^{\mathrm{ab}}$ & $29.65 \pm 0.83^{\mathrm{ab}}$ & $28.15 \pm 1.04^{\mathrm{bc}}$ & $28.45 \pm 2.36^{\mathrm{bc}}$ & $27.15 \pm 2.34^{b}$ & $34.35 \pm 0.84^{\mathrm{ab}}$ \\
\hline & 20 & $30.12 \pm 1.42^{c}$ & $27.15 \pm 1.58^{c}$ & $22.35 \pm 2.03^{c}$ & $26.35 \pm 3.15^{c}$ & $22.15 \pm 3.16^{c}$ & $33.25 \pm 0.28^{c}$ \\
\hline & 40 & $18.26 \pm 2.03^{\mathrm{d}}$ & $24.13 \pm 2.15^{\mathrm{d}}$ & $20.15 \pm 0.59^{d}$ & $23.45 \pm 1.03^{\mathrm{de}}$ & $20.14 \pm 2.15^{\mathrm{cd}}$ & $31.25 \pm 1.28^{\mathrm{d}}$ \\
\hline & 60 & $12.35 \pm 1.78^{\mathrm{e}}$ & $15.54 \pm 3.25^{\mathrm{e}}$ & $19.45 \pm 2.15^{\mathrm{e}}$ & $24.15 \pm 0.19^{\mathrm{e}}$ & $19.65 \pm 1.42^{\mathrm{e}}$ & $25.54 \pm 2.13^{\mathrm{e}}$ \\
\hline & 100 & $14.24 \pm 3.15^{f}$ & $8.15 \pm 0.62^{f}$ & $18.26 \pm 1.03^{f}$ & $13.26 \pm 2.35^{f}$ & $18.56 \pm 3.26^{\mathrm{f}}$ & $21.15 \pm 1.25^{f}$ \\
\hline
\end{tabular}

Data are presented as mean values \pm Standard deviation $(\mathrm{n}=3)$. Statistical analysis: ANOVA test and Duncan test $(\mathrm{p}<0.05)$. Values with the same superscript letters in the same column are not significant. 


\section{Discussion}

Analysis of secondary metabolites and antioxidant properties

The total polyphenol content varies from one species to another. The leaves of the Ziziphyus of Mecca Road presented the highest total polyphenol (62.29 mg GAE/g DM) while Ziziphyus of At-Taif is the lowest one ( $23.65 \mathrm{mg} \mathrm{GAE} / \mathrm{g} \mathrm{DM})$. The variations are probably due to the genetic characteristics of the species and by the environmental conditions in which the plants are found. These results corroborate with those obtained by Bettaieb et al. (2012), Hadacek (2002), Miliauskas et al. (2004), Ebrahimi et al. (2008), Andarwulan et al. (2010). Similar results were reported by Rouz et al. (2015). Our results were higher than those obtained for the Ziziphyus spina-christi Tunisian provenances (Elaloui et al., 2016a; 2016b) where trees are from a young age than ours. This variability the total polyphenol levels could reflect the influence of the geographic conditions (humidity, temperature, altitude), the soil-growth conditions, and the origin and the period of leaves harvest (Brito et al., 2015). The methanol was found to be the efficient solvent to extract Ziziphyus leaves. This idea was also confirmed by Medini et al. (2014). Indeed, the increase in the biosynthesis and accumulation of phenolic compounds occurs frequently in plant tissue in response to biotic and abiotic stresses. These compounds are involved in the defence against reactive oxygen species (ROS), which are inevitably produced when the aerobic metabolism or photosynthetic is weakened by environmental stress. Genetic factors and growth conditions of the plant can also play an important role in the formation of secondary metabolites, including phenolic acids (Islam et al., 2003; Hashempour et al., 2010). Other factors especially the extraction method and the quantification method may also influence the estimate of the content of total phenols (Lee et al., 2003). The polyphenols played an important role in disease resistance by exerting free-radical scavenging, modulation of enzymatic activity and alteration of signal transduction pathways (Elaloui et al., 2016a). This study revealed a strong influence of the localities on the constituent of the leafs extracts. This composition could also be influenced by the extraction time and the ratio of aqueous methanol (Elaloui et al., 2016c). As well, this variability could be explained by many factors including the origin, the period of harvest, the age and the stage of plant development. Other environmental factors (temperature, altitude, sunshine, animal aggression and diseases) could also influenced this variability (Elaloui et al., 2017). The amount of flavonoids of $Z$. spina-christi significant varied $(\mathrm{P}<0.01$ ) between 6.35 (At-taif provenance) and $15.45 \mathrm{mg} Q \mathrm{QE} / \mathrm{g} \mathrm{DM}$ for Jeddah provenance. With the same method, Z. spina-christi leaves for our provenance had more important flavonoid levels than those obtained for Z. joazeiro (Elaloui et al., 2016a; 2016b; Adzu and Haruna, 2007). Similar results were reported by Rouz et al. (2015). It has been proven that the contents of total phenols and flavonoids are high. The difference in the phenolic content including flavonoids described in the literature can be attributed to several factors such as the extraction method and the quantification method. Moreover, variables such as temperature, humidity and light intensity, added to the effects of the biota and the physiochemical structure of the soil can affect not only the production of secondary metabolites but also the chemical structure of substances (Reigosa et al., 2013). It has been proved that the levels of total phenols and flavonoids were high when the environment conditions of the plant were not adequate. In this case, the plant promoted the synthesis of secondary metabolites in order to adapt and survive Tim and Lamb (2005). A few papers reported the amount of phenolics in some of plants; recently, in a review about the biochemical composition of different parts of Z. lotus, Azize (2016) reported around $7 \mathrm{mg} / \mathrm{g}$ of phenolics to be present in the leaves, almost 5 times less than the amount measured in Tlili et al. (2019). Moreover, in the same review, the tannin content observed in the leaves was the same that Tlili et al. (2019) measured (around $3.0 \mathrm{mg} / \mathrm{g}$ ). Conversely, the content of phenolics in the leaves of T. hirsuta and R. tripartitum, including flavonoids, and the DPPH values found by Akrout et al. (2011) and Itidel et al. (2013) were in line with those measured by Tlili et al. (2019). Habib et al. (2014), studied the phenolic compounds in some types of honeys including $Z$. spina-christi L. Sidr honey which was found to contain the highest amount of total phenolics. Z. spina-christi L. samples were obtained from two different regions in Yemen. Ours results were in consistence with those obtained in $Z$. mauritiana (IC50 = $0.11 \mathrm{mg} / \mathrm{mL}$ ) (Ashraf et al., 2015). Ours studies showed that the 
antioxidant activity augmented by the increase in total phenol levels. Adzu and Haruna (2007) also confirmed this idea. For Ziziphyus lotus (L.) Tlili et al. (2019) found the same results as we found in our study. When Alghazeer et al. (2012) studied the antioxidant activity of some plants growing in Libya, he found two times

higher the amount of polyphenols in Hyoscyamus albus than we found in this study. The flavonoids in honey make it a good source of antioxidants (Bader et al., 2020).

\section{Effects of aqueous $Z$. spina-christi leaf extracts on L. culinaris and T. foenum-graecum}

\section{Effects on seed germination}

For both target species (L. culinaris and T. foenum-graecum), the highest germination was obtained for the control and inhibition of germination, which increases by elevating the concentration of aqueous extracts. The concentration of $100 \mathrm{~g} / \mathrm{l}$ gives the lowest germination for both species with a respective L. culinaris and $T$. foenum-graecum of 8 at $19 \%$ and 2 at 12\%. Similar results were reported by Rouz et al. (2015). Inhibitory effect on germination and seedling development were obtained especially at higher concentrations $(60$ and $100 \mathrm{~g} / \mathrm{l})$. Similar findings were also recorded by many researchers (Arora et al., 2015; Prasad et al., 2016; Turker et al., 2008). The degree of inhibition was largely dependent on the concentration of the aqueous extracts (Turk et al., 2002). These results confirm the herbicidal properties of this medicinal specie of Z. spina-christicontaining natural molecules like juglone and artemisin that affect membrane permeability, water balance and osmotic regulation (Sanchez-Moreiras et al., 2008).

\section{Effects on root and shoot lengths}

Ours results showed that interaction between level of concentration of aqueous extracts and species decrease significantly the roots growth. Similar results were reported by Rouz et al. (2015). With the concentrations of $100 \mathrm{~g} / \mathrm{l}$ the length of the roots of L. culinaris varied between 8.16 and $18.15 \mathrm{~mm}$ and the shoot varied between 8.15 and $21.15 \mathrm{~mm}$. With same concentration the length of the roots of $T$. foenumgraecum varied between 4.36 and $16.84 \mathrm{~mm}$ and the shoot varied between 6.45 and $19.35 \mathrm{~mm}$. The root lengths were more inhibited than shoot lengths. These results are in agreement with those of Patil and Kore (2016). These results show that the aqueous extracts of the six provenances of Ziziphyus studied have allelopathic potential and significantly inhibit the germination and growth of $T$. foenum-graecum and $L$. culinaris. These excerpts are provided with a potent cytotoxic activity. Root growth is more sensitive to different concentrations of aqueous extracts of six provenances of this medicinal specie than germination. Turk and Tawaha (2002) concluded that the aqueous extracts of allelopathic plants generally act on root growth rather than growth of the hypocotyl. This was explained by the fall, which made the roots in contact with the first allelochemicals inhibit cell division in meristematic tissues (Ashrafi et al., 2008). Mitosis is the most important event in the development of the plant and many enzymes and regulatory factors of these phenomena are affected by allelochemicals via a chromosome aberration (Turker et al., 2008). Thus, the aqueous extract can affect the absorption of water by the seed and delay the mobilization of reserves (Kato-Noguchi and Macias, 2006). Even if the seed happens to germinate, we recorded a blocking root growth and / or the aerial part of plants. Tucker et al. (2008) reports that the growth phenomenon is more sensitive to the phytotoxic allelochemicals than germination. So, the exact identity of the compounds responsible for this apparent phytotoxic activity, and quantified with certainty needs to be known. Overall, the observed results could form the basis for further investigations of the biological properties of aqueous extracts of six provenances of this medicinal specie. In addition, the use of these aqueous extracts as a biopesticide is a promising path towards recovery of this fraction.

\section{Conclusions}

This study demonstrated that allelopathic potential of aqueous extracts of six provenances of medicinal specie (Ziziphyus) and invasive grass by influencing either the germination or growth are the two phenomena 
that target both species. This indicates that these extracts are rich in natural bioactive substances, suggesting that their importance in the development of natural bioherbicides as an alternative to minimize the release of synthetic non-degradable molecules in crop production. Further studies are needed to understand the mode of action of these allelochemicals. Also, a separation, purification and identification of bioactive molecules that could potentially be used as herbicides or as plant growth regulators would be need to be recorded for further study. Allelopathy, used as herbicides, had an economic benefit to farmers and also reduced negative impacts on the environment and on the health of the human being. In conclusion, all the data confirm the importance of the Saudi Arabia local vegetation as a potential source of various bioactive phytochemical compounds; the investigation is based on the need for different biological agents from natural sources with potent activity and lesser side effects as substitutes for chemical therapeutics.

\section{Authors' Contributions}

Both authors read and approved the final manuscript.

\section{Acknowledgements}

This research received no specific grant from any funding agency in the public, commercial, or not-forprofit sectors.

\section{Conflict of Interests}

The authors declare that there are no conflicts of interest related to this article.

\section{References}

Abdel-Zaher AO, Salim SY, Assaf MH, Abdel-Hady RH (2014). Effect of silver nanoparticles on rice (Oryza sativa L. cv. KDML 105) seed germination and seedling growth. Ecotoxicology and Environmental Safety 104:302-309. https://doi.org/10.1016/j.ecoenv.2014.03.022

Abdoul-Azize S (2016). Potential benefits of jujube (Zizyphus lotus L.) bioactive compounds for nutrition and health. Journal of Nutrition and Metabolism https://doi.org/10.1155/2016/2867470

Adzu B, Haruna AK (2007). Studies on the use of Zizyphus spina-christi against pain in rats and mice. African Journal of Biotechnology 6:1317-1324.

Akrout A, Gonzalez LA, El Jani H, Madrid PC (2011). Antioxidant and antitumor activities of Artemisia campestris and Thymelaea hirsuta from southern Tunisia. Food and Chemical Toxicology 49(2):342-347. https://doi.org/10.1016/j.fct.2010.11.003

Alansi S, Tarroum M, Al-Qurainy F, Khan S, Nadeem M (2016). Use of ISSR markers to assess the genetic diversity in wild medicinal Ziziphyus spina-christi (L.) Willd. collected from different regions of Saudi Arabia. Biotechnology \& Biotechnological Equipment 30(5):942-947. https://doi.org./10.1080/13102818.2016.1199287

Alghazeer HE, Saleh N, Al-Najjar A, Hebail F (2012). Antioxidant and antimicrobial properties of five medicinal Libyan plants extracts. Natural Science 4(5):324-335. https://doi.org/10.4236/ns.2012.45045

Al-Hassan HO (2006). Wild plants of the northern region of the kingdom of Saudi Arabia (field guide with photographs). Ministry of Agriculture, Camel and Range Research Center, Al-Jouf, Saudi Arabia. 
Alqarni A, Hassan A, Owayss A (2015). Evaluation of Acacia gerrardii Benth. (Fabaceae: Mimosoideae) as a honey plant under extremely hot-dry conditions: Flowering phenology, nectar yield and honey potentiality. Journal of Animal and Plant Sciences 25(6):1667-1674.

Alqarni AS (2015). Honeybee foraging, nectar secretion, and honey potential of wild jujube trees, Ziziphyus nummularia. Neotropical Entomology 44(3):232-241. https://doi.org/10.1007/s13744-015-0279-4

Andarwulan N, Batari R, Sandrosari DA, Bolling B, Wijaya H (2010). Flavonoid content and antioxidant activity of $\begin{array}{lllll}\text { vegetable from } & \text { Indonesian. }\end{array}$ https://doi.org/10.1016/j.foodchem.2010.01.033

Arora K, Batish DR, Singh HP, Kohli RK (2015). Allelopathic potential of the essential oil of wild marigold (Tagetes minuta L.) against some invasive weeds. Journal of Environmental and Agricultural Sciences 3:56-60.

Asharafi ZY, Sadeghi S, Mashhadi HR, Alizade HM (2008). Study of allelopathical effects of barley on inhibition of germination and growth of seeding green foxtail. An Open Access Journal published by ICRISA 6:1-6

Ashraf A, Sarfraz RA, Anwar F, Shahid SA, Alkharfy KM (2015). Chemical composition and biological activities of leaves of Ziziphyus mauritiana L. native to Pakistan. Pakistan Journal of Botany 47:367-376.

Azim UM (2008). Allelopathy: Advances, challenges and opportunities. Allelopathy in Sustainable Agriculture and Forestry pp 25-38. https://doi.org/10.1007/978-0-387-77337-7_2

Badr SF, El-Sherif NA, Shabana I, El-Deeb M, AL-Shinqiti FYM (2020). Evaluation of genetic variation, antioxidant and antibacterial activities of two Sidr varieties in Medinadoi. Pakistan Journal of Pharmaceutical Sciences 33(1):6169. http://doi.org/10.36721/PJPS.2020.33.1.REG.061-069.1

Basuny AM, Shaker MA, Hoda AF (2013). Utilization from fruits and leaves of Napek (Zizyphus spina-christi) as a source of bioactive components. International Journal of Chemical and Natural Science 1:29-36.

Bettaieb A, Moujahed N, Ksouri R (2012). Secondary coumpounds characterization in some autochthonous species from a Northern-Eastern region of Tunisia. Options Méditerranéennes. Série A, Séminaires Méditerranéens 102:371374.

Bhadoria PPS (2011). Allelopathy: A natural way towards weed management. American Journal of Experimental Agriculture 1:7-20.

Brito SMO, Coutinho HDM, Talvani A, Coronel C, Barbosa AGR, Vegad C, ... Menezes IRA (2015). Analysis of bioactivities and chemical composition of Ziziphyus joazeiro Mart. using HPLC-DAD. Food Chemistry 186:185191. https://doi.org/10.1016/j.foodchem.2014.10.031

Bukar M, Kyari MZ, Gwaski PA, Gudusu M, Kuburi FS, Abadam YI (2015). Evaluation of phytochemical and potential antibacterial activity of Ziziphyus spina-christi L. against some medically important pathogenic bacteria obtained from University of Maiduguri Teaching Hospital, Maiduguri, Borno State - Nigeria. Journal of Pharmacognosy and Phytochemistry 3:98-101.

Chaudhary SA (1999-2001). Flora of the Kingdom of the Saudi Arabia, vols. 1-3, Riyadh. Ministry of Agriculture and Water press.

Chaudhary SA (2000). In: Flora of the Kingdom of the Saudi Arabia, vol. II. Ministry of Agriculture and Water, Riyadh, Saudi Arabia.

Chaudhary SA (2001). Flora of the Kingdom of Saudi Arabia (Illustrated). Riyadh. National Agriculture and Water Research Center.

Chaudhary SA (2001). In: Flora of the Kingdom of the Saudi Arabia, vol. III. Ministry of Agriculture and Water, Riyadh, Saudi Arabia.

Chaudhary SA, Akram M (1987). Weeds of Saudi Arabia and the Arabian Peninsula. Regional Agriculture and Water Research Center, Ministry of Agriculture and Water, Riyadh, Saudi Arabia.

Chaudhary SA, Al-Jowaid AA (1999). Vegetation of the Kingdom of Saudi Arabia. National Agriculture and Water Research Center. Ministry of Agriculture and Water. Riyadh, Saudi Arabia.

Collenette S (1999). Wild Flowers of Saudi Arabia, Riyadh, National Commission for Wild Life Conservation and Development (VCWCD), pp 779.

Cope T (1985). A key to the grasses of Arabian Peninsula (Studies in the Flora of Arabia XV). Arabian Journal Science Research, Special Publication.

Dafni A, Levy S, Lev E (2005). The ethnobotany of Christ's Thorn Jujube (Ziziphus spina-christi) in Israel. Journal of ethnobiology and ethnomedicine 1(1):8. https://doi.org/10.1186/1746-4269-1-8 
Dewanto V, Wu X, Adom K, Liu RH (2002). Thermal processing enhances the nutritional value of tomatoes by increasing total antioxidant activity. Agriculture and Food Chemistry 50(10):3010-3014. https://doi.org/10.1021/jf0115589

Earp CF, Akingbala JO, Ring SH, Rooney LW (1981). Evaluation of several methods to determine tannins in sorghums with varying kernel characteristics. Cereal Chemistry 58:234-248.

Ebrahimi NS, Hadian J, Mirjalili MH, Sonboli A, Yousefzadi M (2008). Essential oil composition and antibacterial activity of Thymus caramanicus at different phenological stages. Food Chemistry 110:927-931. https://doi.org/10.1016/j.foodchem.2008.02.083

Elaloui M, Ennajah A, Ghazghazi H, Ben YI, Ben ON, Hajlaoui MR, ... Laamouri A (2017). Quantification of total phenols, flavonoides and tannins from Ziziphyus jujuba (mill.) and Ziziphyus lotus (1.) (Desf). Leaf extracts and their effects on antioxidant and antibacterial activities. International Journal of Secondary Metabolite 4(1):18-26.

Elaloui M, Ghazghazi H, Ennajah A, Manaa S, Guezmir W, Karray NB, Laamouri A (2016a). Phenolic profile, antioxidant capacity of five Ziziphyus spina-christi (L.) Willd provenances and their allelopathic effects on Trigonella foenum-graecum L. and Lens culinaris L. seeds. Natural Product Research 31(10):1209-1213. https://doi.org/10.1080/14786419.2016.1226830

Elaloui M, Laamouri A, Ennajah A, Cerny M, Mathieu C, Vilarem G, ... Hasnaoui B (2016c). Phytoconstituents of leaf extracts of Ziziphyus jujuba Mill. plants harvested in Tunisia. Industrial Crops and Product 83:133-139. https://doi.org/10.1016/j.indcrop.2015.11.029

Elaloui M, Soltani I, Laamouri A, Ennajah A, Houcine S (2016b). Allelopathic activity of extracts from leaves of Ziziphyus spina-christi collected in fie Tunisian ecotypes. International Journal of Innovation Science and Research 20:333342.

El-Ansary A, Warsy A, Daghestani M, Merghani NM, Al-Dbass A, Bukhari W, ... Shafi BR (2018). Characterization, antibacterial, and neurotoxic effect of green synthesized nanosilver using Ziziphyus spina Christi aqueous leaf extract collected from Riyadh, Saudi Arabia. Materials Research Express 5:25-33. https://doi.org/10.1088/20531591 /aaaf5f

Farooqi A (1997). Plants of the Qur'an (Lucknow, India). Sidrah Publishers) pp 65-74.

Habib HM, AlMeqbali FT, Kamal H, Souka UD, Ibrahim WH (2014). Bioactive components, antioxidant and DNA damage inhibitory activities of honeys from arid regions. Food Chemistry 153:28-34. https://doi.org/10.1016/j.foodchem.2013.12.044

Hadacek F (2002). Secondary metabolites as plant traits: current assessment and future perspectives. Critical Reviews in Plant Sciences 21(4):273-322. https://doi.org/10.1080/0735-260291044269

Hammi KM, Jdey A, Abdelly Ch, Majdoub H, Ksouri R (2015). Optimization of ultra sound assisted extraction of antioxidant compounds from Tunisian Zizyphus lotus fruits using response surface methodology. Food Chemistry 184:80-89. https://doi.org/10.1016/j.foodchem.2015.03.047

Hashempour A, Ghazvini, RF, Bakhshi D, Sanam SA (2010). Fatty acids composition and pigments changing of virgin olive oil (Olea europea L.) in five cultivars grown in Iran. Australian Journal of Crop Science 4(4):258-263.

Islam MS, Yoshimot OM, Ishigure K, Okuno S, Yamakawa O (2003). Effect of artificial shading and temperature on radical scavenging activity and polyphenolic composition in sweet potato (Ipomoea batatas L.) leaves. Journal American Society Horticultural Science 128:182-187. https://doi.org/10.21273/JASHS.128.2.0182

Itidel C, Chokri M, Mohamed B, Yosr Z (2013). Antioxidant activity, total phenolic and flavonoid content variation among Tunisian natural populations of Rhus tripartita (Ucria) Grande and Rhus pentaphylla Desf. Industrial Crops and Products 51:171-177.

Jiang JG, Huang XJ, Chen J, Lin QS (2007). Comparison of the sedative and hypnotic effects of flavonoids, saponins, and polysaccharides extracted from Semen Ziziphyus jujube. Natural Product Research 21:310-320. https://doi.org/10.1080/14786410701192827

Kato-Noguchi H, Macaias FA (2006). Possibile mecanisme of inhibition of 6-methoxy-benzoxazoline-2(3H)-one on germination of cress (Lepidium sativum L.). Journal of Chemical Ecology 32:1101-1109. https://doi.org/10.1007/s10886-006-9041-Z

Lee KW, KimYJ, Lee HJ, Lee CY (2003). Cocao has more phenolic phytochemicals and a higher antioxidant capacity than teas and red wine. Food Chemistry 51:7292-7295. https://doi.org/10.1021/jf0344385

Li J W, Ding S D and Ding X L (2005). Comparison of antioxidant capacities of extracts from five cultivars of Chinese jujube. Process Biochemistry 40:3607-3612. https://doi.org/10.1016/j.procbio.2005.03.005 
Medini F, Fellah H, Ksouri R, Abdelly C (2014). Total phenolic, flavonoid and tannin contents and antioxidant and antimicrobial activities of organic extracts of shoots of the plant Limonium delicatulum extremophile. Journal of Taibah University for Science 8:216-224. https://doi.org/10.1016/j.jtusci.2014.01.003

Migahid AM (1996). Flora of Saudi Arabia, vols. I-III. Jeddah: King Abdul Aziz University Press.

Miliauskas G, Venskutonis PR, Van Beek TA (2004). Screening of radical scavenging activity of some medicinal and aromatic plant extract. Food Chemistry 85:231-233. https://doi.org/10.1016/j.foodchem.2003.05.007

Mizrahi Y, Nerd A, Sitrit Y (2002). New fruits for arid climates. In: Janick J, Whipkey A (Eds). Trends in new crops and new uses. Alexandria (VA): ASHS Press pp 378-384.

Owayss AA, Elbanna K, Iqbal J, Abulreesh HH, Organji SR, Raweh HSA, Alqarni AS (2020). In vitro antimicrobial activities of Saudi honeys originating from Ziziphyus spina-christi L. and Acacia gerrardii Benth. trees. Food Science \& Nutrition 8:390-401. http://doi.org/10.1002/fsn3.1320

Patil RB, Kore BA (2017). Phytoconstituents, pigments, gas chromatography mass spectrometry analysis, and allelopathy effect of alternanthera ficoidea (L.) P. Beauv. Asian Journal of Pharmaceutical and Clinical Research 10:103-108. https://doi.org/10.22159/ajpcr.2017.v10i2.14498

Popova M, Bankova V, Butovska D, Petkov V, Nikolova-Damyanova B, Sabatini AG, ... Bogdanov S (2004). Validated methods for the quantification of biologically active constituents of poplar-type propolis. Phytochemical Analysis: An International Journal of Plant Chemical and Biochemical Techniques 15(4):235-240. https://doi.org/10.1002/pca.777

Prasad R, Tripathi VD, Singh P, Handa AK, Alam B, Singh R, Chaturvedi OP (2016). Allelopathic potential of Butea monosperma L.: Effect of aqueous leaf extract on seed germination and seedling growth of winter season (rabi) crops. Indian Journal of Agroforestry 18:63-69.

Reigosa M, Gomes AS, Ferreira AG, Borghetti F (2013). Allelopathic research in Brazil. Acta Botanica Brasillica 27(4):629-646. https://doi.org/10.1590/S0102-33062013000400001

Rice-Evans CA, Miller NJ, Paganga G (1996). Structure-antioxidant activity relationships of flavonoids and phenolic acids. Free Radical Biology and Medicine 20:933-956. https://doi.org/10.1016/0891-5849(95)02227-9

Rouz S, Ben Farhat M, Gammar-Ghrabi Z (2015). The aqueous extract effect of six species on the chicory adventitious of the berseem fields in Tunisia. Journal of New Sciences, Agriculture and Biotechnology 20(4):798-803.

Saanchez-Moreiras AM, Coba de la Pena T, Reigosa MJ (2008). The natural compound benzoxazolin-2(3H) one selectively retards cell cycle in lettuce root meristems. Phytochemistry 69:2172-2179. https://doi.org/10.1016/j.phytochem.2008.05.014

Seif Eldin AM, Ahmed SK, Walid SK, Azim MK (2015). Antigiardial activity of glycoproteins and glycopeptides from Ziziphyus honey. Natural Product and Research 22:2100-2102. https://doi.org/10.1080/14786419.2014.986659

Singleton VL, Orthofer R, Lamuela-Raventos RM (1999). Analysis of total phenols and other oxidation substrates and antioxidants by means of Folin Ciocalteu reagent. Methods in Enzymology 299:152-178. https://doi.org/10.1016/S0076-6879(99)99017-1

Tim TPC, Lamb AJ (2005). Antimicrobial activity of flavonoids. International Journal of Antimicrobial Agents 26:343356. https://doi.org/10.1016/j.ijantimicag.2005.09.002

Tlili H, Hanen N, Ben Arfa A, Neffati M, Boubakri A, Buonocore D (2019). Biochemical profile and in vitro biological activities of extracts from seven folk medicinal. Plants growing wild in southern Tunisia. PLoS One 14(9):30213049. https://doi.org/10.1371/journal.pone.0213049

Turk M, Shatnawi AMK, Tawaha A M (2002). Inhibitory effects of aqueous extracts of black mustard on germination and growth of alfalfa. Weed Biology and Management 3:37-40. https://doi.org/10.1046/j.14456664.2003.00079.x

Turk MA, Tawaha AM (2002). Inhibitory effects of aqueous extract of barely on germination and growth of lentil. Pakistan journal of Agronomy 1:28-30. https://doi.org/10.3923/ja.2002.28.30

Turker M, Bttal P, Agar G, Guluce M, Sahin F, Yildirim N (2008). Allelopathic effects of plants extracts on physiological process during maize seed germination. Allelopathy Journal 21:273-286.

Waggas AM, Al-Hasani RH (2010). Neurophysiological study on possible protective and therapeutic effects of Sidr (Zizyphus spina-christi L.) leaf extract in male albino rats treated with pentylenetetrazol. Saudi Journal of Biological Sciences 17:269-274. https://doi.org/10.1016/j.sjbs.2010.05.003 
OPEN ACCESS

(c) (i)

The journal offers free, immediate, and unrestricted access to peer-reviewed research and scholarly work. Users are allowed to read, download, copy, distribute, print, search, or link to the full texts of the articles, or use them for any other lawful purpose, without asking prior permission from the publisher or the author.

License - Articles published in Notulae Botanicae Horti Agrobotanici Cluj-Napoca are Open-Access, distributed under the terms and conditions of the Creative Commons Attribution (CC BY 4.0) License. (C) Articles by the authors; UASVM, Cluj-Napoca, Romania. The journal allows the author(s) to hold the copyright/to retain publishing rights without restriction. 